\title{
Endophytic Bacterial and Fungi Associated to Banana Leaves (Musa spp.) Cultivated Under Organic Management
}

\author{
Carlos A. Souza Junior ${ }^{1.2}$, Joelma Marcon ${ }^{3}$, Pedro Avelino M. Andrade ${ }^{3}$, José Antonio Silva ${ }^{3}$, \\ Maria Inez F. Faraldo ${ }^{3}$, Maria Carolina Q. Verdi ${ }^{3}$, Antonio A. Melo Filho ${ }^{4} \&$ João Lúcio Azevedo ${ }^{3}$ \\ ${ }^{1}$ PPG BIONORTE, State University of Amazonas, Manaus, AM, Brazil \\ ${ }^{2}$ LEDUCARR, Federal University of Roraima, Boa Vista, RR, Brazil \\ ${ }^{3}$ School of Agriculture "Luiz de Queiroz", University of São Paulo, SP, Brazil \\ ${ }^{4}$ PPG BIONORTE, Federal University of Roraima, Paricarana Campus, Boa Vista, RR, Brazil \\ Correspondence: Carlos A. Souza Junior, LEDUCARR, Federal University of Roraima, CEP 69304-000, Boa \\ Vista, RR, Brazil. E-mail: junior.asjr@gmail.com
}

Received: June 30, $2018 \quad$ Accepted: August 2, $2018 \quad$ Online Published: September 15, 2018

doi:10.5539/jas.v10n10p460 URL: https://doi.org/10.5539/jas.v10n10p460

\begin{abstract}
Banana as a domesticated plant has a long evolutionary history of cultivation and has become one of the most important fruit in a world widely market, devoted to its high nutritional characteristics. However, its biology and association with microbes are poorly understood. Then the objective of the present study was isolate the cultivable endophytic bacterial and fungal community associated to leaves of an organic banana plantation in the Brazilian Amazon state of Roraima. A total of 24 fungi and 27 bacteria isolates were selected. The taxonomical classification showed that the cultivable endophytic fungi community is affiliated to the following 11 genera: Aspergillus, Peniophora, Meyerozyma, Saccharicola, Hypocreales, Nigrospora, Byssochlamys, Periconia, Myrothecium, Acrocalymma and Peroneutypa. Regarding the bacterial isolates 13 genera were found: Serratia, Pantoea, Streptococcus, Neisseria, Bacillus, Arsenicicoccus, Sphingobacterium, Herbaspirillum, Lactococcus, Variovorax, Pseudorhodoferax, Stenotrophomonas and Brevibacterium. Comparing the endophytic microorganisms isolated in the present research with previous studies already published, some new genera and species were detected. This could be due to use of organic cultivated bananas without the utilization of fertilizers and other chemical products. This could provide the isolation of bacteria and fungi which are benefic to their hosts but not yet previous found in banana.
\end{abstract}

Keywords: agriculture, Musaceae, organic plantation, Brazilian Amazon

\section{Introduction}

Banana is one of the main fruits cultivated in the world, comprising a fruit largely exported and consumed in many tropical countries. Brazil is characterized as a gross producer being the fourth country in a scale of area planted (FAO, 2015). The expansion of banana cultivation mainly due to the high nutritional characteristics related to vitamins and minerals, and its production are mostly related to a great number of producers, however, in many cases is the most important source of income from small to big producers. Opposed to this high production, the development of banana in field has undergone several difficulties caused by attack from insect pests, microbial diseases that drive the lack of plants of good quality (Pereira et al., 1999; Su et al., 2017; Souza et al., 2013; Zakaria \& Rahman, 2011; Kavino \& Manoranitham, 2018).

The first to describe no pathogenic fungi living inside plants was De Bary (1866) which named them as endophytes. After that, bacteria and other microorganisms were also found practically in all host plants studied. From about 40 years ago the endophytic microbiota started to be considered as beneficial to their plant hosts protecting them against insect pests and also diseases caused by pathogenic bacteria, fungi and nematodes (Kavino \& Manoranjithan, 2018; Su et al., 2017; Souza et al., 2014; Thangalevu \& Gopi, 2015).

Other beneficial properties were also added as endophytes producing growth hormones, able to fix atmospheric nitrogen and causing phosphate solubilization (Karthik et al., 2017; Souza et al., 2013; Souza et al., 2017; Muthuri et al., 2012; Ting et al., 2008; Andrade et al., 2014; Benzon et al., 2014). In Brazil, the Roraima state located in the Amazon North region of the country is expanding the production of banana. The average 
production in this region is lower than that found in other parts of the country. The low productivity demands also use of agrochemicals which increase production costs. One alternative is the use of banana endophytes which could act as biological controllers and increase growth production as a sustainable and environmental safe practice to improve banana growth. As far as we know, related papers isolating endophytes from banana all over the world, utilize cultures subject to the use of fertilizers, insecticides, fungicides, nematicides and other antimicrobials in general.

In the present research we isolated endophytic, both bacteria and fungi, from organic cultures of banana. This probably provide ways to avoid the reduction in number and genera of isolated microorganisms increasing the probability to found beneficial ones which could increase productivity with reduction of economic costs and helping the ecological environmental conditions.

\section{Material and Methods}

\subsection{Plant Material and Sampling Procedure}

Banana leaves were collected in November 2017 from the São Pedro farm located in state of Roraima, city of

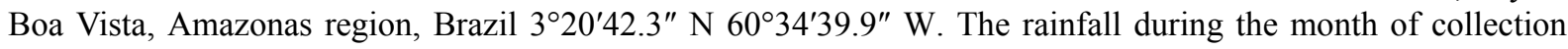
was $00 \mathrm{~mm}$, average temperature was $33.5^{\circ} \mathrm{C}$ and the relative medium humidity was $44.0 \%$.

\subsection{Fungi Assessment and Culturing Conditions}

The procedure described by Araujo et al. (2014), with modifications adapted to banana was used. Surface of 20 leaves, about $85 \mathrm{~cm}$ length and $20 \mathrm{~cm}$ wide with veins, were fragmented in smaller pieces and sterilized by immersion in $70 \%$ ethanol for 1 minute, sodium hypochlorite 3\% for 4 minutes, and finally ethanol $70 \%$ for 30 sec. After surface sterilization the fragments were rinsed two times in autoclaved distilled water. The effectiveness of the method was verified by plating $0.1 \mathrm{~mm}$ of the final rinse in Petri dishes containing potato dextrose agar medium (BDA) supplemented with tetracycline to prevent bacterial growth. Only considered surface sterilized fragments were used for next fungal endophytic isolation. Smaller fragments of about $0.5 \mathrm{~cm}$ were then prepared from the previous fragments and placed on dish plates containing BDA medium as mentioned before. Five fragments were inoculated to each dish in a total of 250 fragments. The plates were incubated from 7 to 12 days at $28{ }^{\circ} \mathrm{C}$. The colonization frequency was determined by the ratio between the number of fragments colonized by fungi and the total number of fragments used. Purification of isolates was performed using morphological characterization of distinct forms and their frequency. Single purified colonies were used for molecular identification. Both this procedure 2.2 and item 2.3 had as main objective to eliminate the microorganisms that live on the surface of the banana leaves, because the focus of this study and the line of research of this work were the endophytic microorganisms, which live inside the leaves that protect them against pathogenic invaders in general.

\subsection{Bacterial Assessment and Culturing Conditions}

The bacterial isolation was performed according to Araujo et al. (2014). The total of $5 \mathrm{~g}$ of leaves were macerated and placed in flasks containing $90 \mathrm{~mL}$ of phosphate buffer solution (PBS) containing NaCl, $9.0 \mathrm{~g} ; \mathrm{KCl}$, $0.2 \mathrm{~g} ; \mathrm{Na}_{2} \mathrm{HPO}_{4}, 1.44 \mathrm{~g}$ and $\mathrm{KH}_{2} \mathrm{PO}_{4}, 0.24 \mathrm{~g}$ distilled water $1000 \mathrm{~mL}, \mathrm{pH}$ 7.4). Samples were incubated under agitation $\left(150 \mathrm{rpm}\right.$ ) for 30 minutes at $28{ }^{\circ} \mathrm{C}$. Aliquots of $0.1 \mathrm{~mL}$ of three-fold serial dilutions were inoculated in duplicate onto petri dishes plates with $20 \mathrm{~mL} 10 \%$ triptone soy agar medium (TSA) including $50 \mu \mathrm{g} \cdot \mathrm{mL}^{-1}$ benomil to avoid fungal growth. The plates were incubated at $28{ }^{\circ} \mathrm{C}$ and colonies were counted starting from 48 hours incubation. Colonies were selected considering their color and shape, and purified being preserved in $15 \%$ glycerol at $-80^{\circ} \mathrm{C}$ to be used for molecular identification analysis.

\subsection{DNA Isolation}

The bacterial strains were cultured in $5 \mathrm{~mL}$ TSA $10 \%$ liquid for $24 \mathrm{~h}$ at $28^{\circ} \mathrm{C}$ under $150 \mathrm{rpm}$ stirring. $5 \mathrm{~mL}$ of the culture were centrifuged for $5 \mathrm{~min}$ at $14,000 \mathrm{~g}$ and the resuspended cells in $500 \mu \mathrm{L} \mathrm{TE}(10 \mathrm{mM}$ Tris- $\mathrm{HCl} \mathrm{pH} \mathrm{8.0)}$ were centrifuged and resuspended again in $500 \mu \mathrm{L}$ TE with the addition of $0.5 \mathrm{~g}$ of glass beads $(0.1 \mathrm{~mm}$ in diameter-Sigma) and $15 \mu \mathrm{L}$ of $20 \%$ SDS. Cells were shaken in a homogenizer (Mine-BeadbeaterTM, Biospec Products) for $30 \mathrm{sec}$ at $3500 \mathrm{bpm}$. To the cell lysate were added $500 \mu \mathrm{L}$ of phenol, homogenized by inversion and centrifuged for $5 \mathrm{~min}$ at $14,000 \mathrm{~g}$. The aqueous phase was extracted once with phenol-chloroform $(1: 1)$ and once with chloroform, then the DNA was precipitated with $1 / 10$ volume of $5 \mathrm{M} \mathrm{NaCl}$ and 0.6 volume of isopropanol (3 minutes at room temperature) and collected by centrifugation (10 minutes at 14,000 g). The DNA precipitate was washed with $70 \%$ ethanol, dried at $37{ }^{\circ} \mathrm{C}$ and resuspended in $50 \mu \mathrm{L}$ of sterilized milli-Q water. Total DNA was analyzed by agarose gel electrophoresis $(0.8 \% \mathrm{w} / \mathrm{v})$ in $1 \mathrm{x}$ TrisAcetateEDTA buffer (TAE) buffer (40 mM de 
Tris-acetate; $1 \mathrm{mM}$ EDTA) stained with ethidium bromide (EB) $\left(0.5 \mu \mathrm{g} \mathrm{mL} \mathrm{m}^{-1}\right)$, according to Kuklinsky et al. (2004).

The fungi strain were cultured onto fifth $\mathrm{mL}$ of the liquid medium BDA ( $200 \mathrm{~g}$ potato broth and $20 \mathrm{~g}$ dextrose in $1 \mathrm{~L}$ water, [pH 6.0]) for 5 to 7 days at $28^{\circ} \mathrm{C}$. After this period of culture growth and multiplication, the whole content was centrifuged at 20,000 g for 10 minutes to remove the excess culture medium. The precipitated was subjected to a filtration process for water elimination. Subsequently, approximately $100 \mathrm{mg}$ was triturated in liquid nitrogen. The isolate was submitted to a DNA extraction using the Genomic Wizard complete DNA purification kit (Promega Corporation, Wisconsin, USA), following the manufacturer's instructions. The DNA extracted, as well as its quantification was determined by $1.2 \%$ agarose gel electrophoresis medium $(\mathrm{w} / \mathrm{v})$, the gel stained with an EB solution and visualized in ultraviolet light (DNr Bio-Imaging Systems Minibis pro 16 $\mathrm{mm})$.

\subsection{Amplification and Sequencing of the 16S rRNA Gene and ITS Region of the Endophytic Strains}

A sample of 27 bacteria and 24 fungal strains were selected for a partial sequencing of the 16S rRNA gene and the ITS region, respectively. The amplification of the bacterial fragments was performed in a $25 \mu \mathrm{L}$ final volume containing $1 \mu \mathrm{L}(0.5-10.0 \mathrm{ng})$ of total DNA, $0.2 \mathrm{mM}$ of P27F primer (5'-GAGAGTTTGATCCTGGCTCAG-3'), $0.2 \mathrm{mM}$ of 1492R primer (5'-TACGGYTACCTTGTTACGACT-3') (Welsburg et al., 1991), $0.2 \mathrm{mM}$ of each dNTP, $0.02 \mathrm{mg} \mathrm{mL}^{-1} \mathrm{BSA}, 3.75 \mathrm{mM} \mathrm{MgCl}_{2}$ and $0.05 \mathrm{U}$ of Taq DNA polymerase (Fermentas). The reaction was subjected to a temperature-controlled thermal cycler performing an initial denaturation at $94{ }^{\circ} \mathrm{C}$ for 4 minutes, 35 additional cycles of denaturation at $94{ }^{\circ} \mathrm{C}$ for $30 \mathrm{sec}$ each, annealing at $63{ }^{\circ} \mathrm{C}$ for 1 minute and primer extension at $72{ }^{\circ} \mathrm{C}$ for 1 minute, followed by a final extension at $72{ }^{\circ} \mathrm{C}$ for 10 minutes. After amplification, the PCR products were visualized by agarose gel electrophoresis $(1.5 \% \mathrm{w} / \mathrm{v})$ in $1 \mathrm{x}$ TAE buffer.

The ITS-DNA hypervariable region of the strain was amplified using primers ITS-1(5'-TCCGTAGGTGAAC CTGCGG-3') and ITS-4 (5'-TCCTCCGCTTATTGATATGC-3') (WHITE et al., 1990). In a final volume of 50 $\mu \mathrm{L}$ containing 1x Buffer (50 mM KCl, $20 \mathrm{mM}$ Tris-HCl, $\mathrm{pH}$ 8.4); (3.7 mM MgCl $2,1 \mathrm{mM}$ dNTP, $0.05 \mathrm{U}_{\mu \mathrm{L}}^{-1}$ Taq-Invitrogen DNA polymerase), $0.2 \mu \mathrm{M}$ ITS-1 primer, $0.2 \mu \mathrm{M}$ ITS-4 primer and, approximately $5 \mathrm{ng}$ of DNA. The reactions were performed in a thermocycler (Veriti ${ }^{\circledR}$ Thermocycler, Applied Biosystems, Waltham, USA), programmed to an initial denaturation step of $94{ }^{\circ} \mathrm{C}$ for 5 minutes, followed by 30 cycles of denaturation at $94{ }^{\circ} \mathrm{C}$ for $30 \mathrm{sec}, 55^{\circ} \mathrm{C}$ for $30 \mathrm{sec}$ and $72{ }^{\circ} \mathrm{C}$ for $30 \mathrm{sec}$ and a final extension at $72{ }^{\circ} \mathrm{C}$ for 7 minutes.

The amplified fragment (approximately $600 \mathrm{pb}$ ), was visualized onto $1.2 \%$ agarose gel electrophoresis. The gel was stained in ethidium bromide solution and photodocumented under UV light. Subsequently, the amplified fragments were purified with the PCR kit GFX (Amersham Pharmacia Biotech) and Sanger sequenced.

The PCR products were purified using a Super Charger Switch Kit and Sanger sequenced using the 1387R primer (Heuer et al., 1997) and primer ITS4 (White et al., 1990). Analyses of sequences were performed with the basic sequence alignment BLAST program, which was run against the database on the National Center for Biotechnology Information (NCBI) website (http://www.ncbi.nlm.nih.gov/BLAST).

\section{Results}

\subsection{Amplification and Sequencing of Fungal Endophytes}

After purification, twenty-four colonies were selected based on morphology and microscopic examination and further sequenced. The obtained results are presented in Table 1. Only similarities of 96 to $100 \%$ were included as identified isolates. The isolated and identified fungi belonged to the following 11 genera: Aspergillus, Peniophora, Meyerozyma, Saccharicola, Hypocreales, Nigrospora, Byssochlamys, Periconia, Myrothecium, Acrocalymma and Peroneutypa. The species Aspergillus versicolor was the most frequently found. 
Table 1. Genetic characteristics of the endophytic fungi strains isolated from banana leaves and sequenced of the ITS region

\begin{tabular}{|c|c|c|c|}
\hline \multirow{2}{*}{ Strain Code } & \multicolumn{3}{|c|}{ ITS region } \\
\hline & NCBI Best BLAST Hits & Identity (\%) & Ac. Number NCBI \\
\hline FFB01 & Aspergillus versicolor & $97 \%$ & MH453585 \\
\hline FFB02 & Aspergillus versicolor & $99 \%$ & MH453586 \\
\hline FFB03 & Aspergillus versicolor & $98 \%$ & MH453587 \\
\hline FFB04 & Aspergillus versicolor & $99 \%$ & MH453588 \\
\hline FFB05 & Aspergillus versicolor & $99 \%$ & MH453589 \\
\hline FFB06 & Aspergillus versicolor & $99 \%$ & MH453590 \\
\hline FFB07 & Aspergillus sp. & $99 \%$ & MH453591 \\
\hline FFB08 & Peniophora crassitunicata & $98 \%$ & MH453592 \\
\hline FFB09 & Peniophora crassitunicata & $97 \%$ & MH453593 \\
\hline FFB10 & Meyerozyma guilliermondii & $99 \%$ & MH453594 \\
\hline FFB11 & Aspergillus versicolor & $99 \%$ & MH453595 \\
\hline FFB12 & Peniophora crassitunicata & $99 \%$ & MH453596 \\
\hline FFB13 & Peniophora sp. & $99 \%$ & MH453597 \\
\hline FFB14 & Saccharicola $\mathrm{sp}$ & $99 \%$ & MH453598 \\
\hline FFB15 & Hypocreales sp. & $100 \%$ & MH453599 \\
\hline FFB16 & Peniophora crassitunicata & $100 \%$ & MH453600 \\
\hline FFB17 & Nigrospora zimmermanii & $99 \%$ & MH453601 \\
\hline FFB18 & Byssochlamys spectabilis & $99 \%$ & MH453602 \\
\hline FFB19 & Periconia sp. & $98 \%$ & MH453603 \\
\hline FFB20 & Myrothecium sp. & $98 \%$ & MH453604 \\
\hline FFB21 & Acrocalymma vagum & $98 \%$ & MH453605 \\
\hline FFB22 & Byssochlamys spectabilis & $96 \%$ & MH453606 \\
\hline FFB23 & Peniophora sp. & $99 \%$ & MH453607 \\
\hline FFB24 & Peroneutypa scoparia & $99 \%$ & MH453608 \\
\hline
\end{tabular}

\subsection{Amplification and Sequencing of Bacterial Endophytes}

After plating diluted aliquots from endophytic bacteria obtained from macerated leaves of banana trees a total of $9.4 \times 10^{3}$ colonies. $\mathrm{g}^{-1}$ of fresh weight leaves tissues were obtained. From all plates based on morphological colony features bacteria representing about $2 \%$ of total bacteria were chosen, based mainly on shape, margin and colony color. Chosen colonies were further purified and stocked cultures were maintained at $-80{ }^{\circ} \mathrm{C}$ in glycerol. Isolates were taken for DNA isolation and sequencing. The results are shown in Table 2. Only similarities of 97 to $99 \%$ were included as identified isolates. From 27 identified bacteria, 13 following genera were encountered: Serratia, Pantoea, Streptococcus, Neisseria, Bacillus, Arsenicicoccus, Sphingobacterium, Herbaspirillum, Lactococcus, Variovorax, Pseudorhodoferax, Stenotrophomonas, Brevibacterium the most frequently genera found were Herbaspirillum, Serratia and Bacillus. 
Table 2. Genetic characteristics of the endophytic bacteria strains isolated from banana leaves and sequenced of the 16S rRNA gene

\begin{tabular}{|c|c|c|c|}
\hline \multirow{2}{*}{ Strain Code } & \multicolumn{3}{|c|}{ 16S rRNA gene } \\
\hline & NCBI Best BLAST Hits & Identity (\%) & Ac. Number NCBI \\
\hline BFB01 & Serratia marcescens & $98 \%$ & MH447310 \\
\hline BFB02 & Pantoea cypripedii & $99 \%$ & MH447302 \\
\hline BFB03 & Serratia marcescens & $99 \%$ & MH447309 \\
\hline BFB04 & Serratia marcescens & $98 \%$ & MH447308 \\
\hline BFB05 & Streptococcus sp. & $98 \%$ & MH447328 \\
\hline BFB06 & Neisseria $\mathrm{sp}$. & $99 \%$ & MH447327 \\
\hline BFB07 & Bacillus sp. & $98 \%$ & MH447326 \\
\hline BFB08 & Arsenicicoccus bolidensis & $99 \%$ & MH447325 \\
\hline BFB09 & Bacillus circulans & $99 \%$ & MH447324 \\
\hline BFB10 & Arsenicicoccus_sp. & $97 \%$ & MH447307 \\
\hline BFB11 & Sphingobacterium multivorum & $99 \%$ & MH447323 \\
\hline BFB13 & Bacillus cereus & $99 \%$ & MH447322 \\
\hline BFB14 & Bacillus circulans & $99 \%$ & MH447321 \\
\hline BFB15 & Herbaspirillum sp. & $99 \%$ & MH447320 \\
\hline BFB16 & Lactococcus lactis subsp. lactis & $99 \%$ & MH447319 \\
\hline BFB17 & Herbaspirillum sp. & $99 \%$ & MH447318 \\
\hline BFB18 & Neisseria $\mathrm{sp}$ & $99 \%$ & MH447317 \\
\hline BFB19 & Herbaspirillum sp. & $99 \%$ & MH447316 \\
\hline BFB20 & Pseudorhodoferax_aquiterrae & $98 \%$ & MH447306 \\
\hline BFB21 & Variovorax $\mathrm{sp}$ & $97 \%$ & MH447305 \\
\hline BFB22 & Pseudorhodoferax aquiterrae & $99 \%$ & MH447315 \\
\hline BFB23 & Herbaspirillum $\mathrm{sp}$. & $98 \%$ & MH447304 \\
\hline BFB24 & Herbaspirillum sp. & $99 \%$ & MH447314 \\
\hline BFB25 & Herbaspirillum sp. & $99 \%$ & MH447313 \\
\hline BFB26 & Herbaspirillum sp. & $99 \%$ & MH447303 \\
\hline BFB27 & Stenotrophomonas maltophilia & $99 \%$ & MH447312 \\
\hline BFB28 & Brevibacterium permense & $99 \%$ & MH447311 \\
\hline
\end{tabular}

\section{Discussion}

Endophytic microbiota is found practically in all plant hosts studied (Azevedo \& Araujo, 2007). Many endophytic bacteria and fungi are nowadays considered beneficial to their hosts. Several papers are already published showing endophytic microorganisms from bananas (Tables 3 and 4). Isolated endophytic fungi and bacteria from banana produced increase growth promotion (Andrade et al., 2014; Kartick et al., 2017; Muthuri et al., 2012; Souza et al., 2017; Thomas \& Soly, 2009), protect plants against prejudicial bacterial, fungal, nematodes and insect pests (Su et al., 2017; Souza et al., 2014; Thangalevu \& Gopi, 2015; Zakaria \& Rahman, 2011). Most of the studies related to isolation of endophytes from plant hosts are performed in cultures submitted to use of fertilizers and chemical products aiming increasing production and reduction of diseases and pests. As far as we know, the present research may be the first one to isolate endophytic fungi and bacteria from organic cultivated bananas without the use of fertilizers and other chemical products. This could provide the isolation of microorganisms which are benefic to their hosts but not yet isolated due to inhibition by chemical fungicides and other products. 
Table 3. Studies describing the main diversity of fungal genus strains isolated from banana leaves (Musa spp.)

\begin{tabular}{|c|c|c|c|}
\hline Most common fungi genus isolated from Banana leaves & Management & Country & References \\
\hline $\begin{array}{l}\text { Alternaria, Aspergillus, Cordana, Curvularia, Dreshlera, Epicoccum, Fusarium, } \\
\text { Glomerella, Humicola, Nigrospora, Periconia, Phomopsis, Phylosticta, } \\
\text { Trichoderma, Xylaria }\end{array}$ & Convetional & $\mathrm{Brazil}^{\mathrm{a}}$ & Pereira et al. (1999) \\
\hline Xylaria, Guignardia, Colletotrichum, Deightoniella, Pyriculariopsis, Dactylaria & Convetional & Thailand $^{\mathrm{a}}$ & Photita et al. (2001) \\
\hline $\begin{array}{l}\text { Gloeosporium, Myxosporium,Deightoniella, Alternaria, Sphaceloma, } \\
\text { Aureobasidium, Melida, Uncinula, Penicillium, Aspergillus, Sarcinella, } \\
\text { Cladosporium, Cephalosporium, Paecilomyces, Fusarium, Spicaria, Meliola }\end{array}$ & Convetional & China $^{\mathrm{a}}$ & Cao et al. (2002) \\
\hline Fusarium & Convetional & Malaysi $^{\mathrm{b}}$ & Ting et al. (2008) \\
\hline Trichoderma & Convetional & India $^{\mathrm{b}}$ & Thangavelu \& Gopi (2015) \\
\hline Fusarium & Convetional & Malaysi ${ }^{\mathrm{b}}$ & Zakaria \& Rahman (2011) \\
\hline
\end{tabular}

Note. ${ }^{\mathrm{a}}$ Fungal Diversity; ${ }^{\mathrm{b}}$ Fusarium control.

Table 4. Studies describing the main diversity of bacteria genus strains isolated from banana leaves (Musa spp.)

\begin{tabular}{|c|c|c|c|}
\hline Most common fungi genus isolated from Banana leaves & Management & Country & References \\
\hline Enterobacter, Klebsiella, Rhizobium & Conventional & Mexico & Martinez et al. (2003) \\
\hline Serratia & Wild & Malaysia & Ting et al. (2008) \\
\hline Agrobacterium, Klebsiella, Pseudacidovorax & Conventional & India & Thomas \& Soly (2009) \\
\hline Pseudomonas, Bacillus, Streptomyces & Conventional & China & Su et al. (2017) \\
\hline $\begin{array}{l}\text { Pantoea, Pseudomonas, Serratia, Klebsiella, Rhizobium, Microbacterium, } \\
\text { rhodococcus, Bacillus }\end{array}$ & Conventional & India & Karthik et al. (2017) \\
\hline $\begin{array}{l}\text { Agrobacterium, Rhizobium, Aneurinebacillus, Bacillus, Enterobacter, Klebsiella, } \\
\text { Lysinibacillus, Micrococcus, Paenibacillus, Sporolacto bacillus }\end{array}$ & Conventional & Brazil & Souza et al. (2013) \\
\hline Bacillus & Conventional & Brazil & Souza et al. (2017) \\
\hline $\begin{array}{l}\text { Arthrobacter, Brevibacterium, Corynebacterium, Curtobacterium, } \\
\text { Kocuria,Kytococcus, Micrococcus, Naumanella, Rothia, Brevundimonas, } \\
\text { Enterobacter, Klebsiella, Pseudomonas, Serratia, Sphingomonas, Bacillus, } \\
\text { Staphylococcus }\end{array}$ & Conventional & India & Sekhar \& Thomas (2015) \\
\hline Serratia, Pseudomonas, Rahnella, Enterobacter, Klebsiella, Yersinia. Evingella & Conventional & Kenya & Muthari et al. (2012) \\
\hline
\end{tabular}

In the present research several microorganisms were not yet described as banana endophytes by other authors. Of course, this could also be the result from the use of distinct banana cultivars, different climates and regions and distinct use of plant organs and tissues as leaves and, root tips among others. However, the distinct differences encountered as being due to the lack of chemical products and processes inhibiting or reducing the microbial diversity could not be discarded. Among the isolated endophytic fungi and bacteria from our results using the organic bananas, several genera and species were recorded for the first time both in fungi (Tables 1 and 3 ) and in bacteria (Tables 2 and 4). Of course, future studies must be conducted with these isolated microorganisms in an attempt to detected plant growth promotion, reduction of diseases and pests and other beneficial uses as production of antimicrobials substances, enzymes and compounds of biotechnological uses. However, among the newly isolated genera and species from the organic bananas used in the present research, some are related to beneficial and biotechnological uses as for instance the bacterium genus Herbaspirillum, the most frequently detected in our research, known as including species capable of nitrogen fixation and promoting growth of plant hosts (Ebeltagy et al., 2011).

Other bacteria genera also frequently found in our study as Serratia and Bacillus which were already isolated from banana and other plant hosts and proved to be capable of plant growth promotion (Table 4). Other bacteria genera isolated as Pantoea and Variovorax are also important for biotechnological purposes as plant growth promoters, enzymes production and degradation of pollutants (Quecine et al., 2012; Satola et al., 2013). Among the isolated fungi from organic bananas the most frequently one and for the first time recorded in bananas was Aspergillus versicolor which is known to produce antibacterial, fungicidal and insecticidal properties besides enzymes production (Domsch, 2001).

Other fungal isolates as the genus Hypocreales are also cited as possessing biological controller properties. Other found genera as Periconia are related as pathogenic to several plant hosts. These, isolated as endophytic by us may be no pathogenic forms and could be used as controllers of pathogenic forms as related in endophytic 
Fusarium able to control Fusarium oxysporum pathogenic forms in banana (Table 3). Future studies may be conducted to test the properties of the fungi and bacteria isolated in the present study as growth hormones and production, phosphate solubilization, ability to fix nitrogen, as well detection of possible prejudicial properties which could impair their use in growth promotion and biological control among others.

\section{Conclusion}

Isolation of endophytic fungi and bacteria from banana plant plantation using organic practices, resulted in the presence of endophytic genera and species not yet reported from this host as compared to previous studies using conventional practices. The newly isolated endophytes could be tested for biotechnological approaches aiming increase in plant growth promotion, protection against pests and diseases. If successful, these endophytes would help increase production reducing the use of fertilizers and other chemical compounds with cost reduction and environmental ecological benefits.

\section{Acknowledgements}

The authors thank for the funding support of São Paulo Research Foundation (FAPESP Grants Proc. 2015/01188-9 and the scholarship granted by CAPES.

\section{References}

Andrade, L. F., Souza, G. L. O. D., Nietshe, S, Pereira, M. C. T., \& Pereira, D. F. G. S. (2014). Analysis of the abilities of endophytic bacteria associated with banana tree roots to promote plant growth. Journal of Microbiology, 52, 27-34.

Araujo, W. L., Quecine, M. C., Lacava, P. T., Aguilar-Vildoso, C. I., Marcon, J., Lima, A. O. S., ... Azevedo, J. L. (2014). Micro-organismos endofiticos: Aspectos teóricos e práticos de isolamento e caracterização (p. 257). Santarém Editora UFOPA.

Azevedo, J. L., \& Araujo, W. L. (2007). Diversity and applications of endophytic fungi isolated from tropical plants. In B. N. Ganguli, \& S. K. Deshmuckh (Eds.), Fungi multifaceted microbes (pp. 191-207). Anamaya Puublishers, New Delhi.

Benzon, H. R. L., Mendoza, D. M., Cosico, W. C., \& Torreta, N. K. (2014). The effect of endophytic bacterial inoculation on banana, Musa acuminata cv. Lakatan. Philipine Journal of Crop Science, 39, 12-21.

Cao, L. X., You, J. L., \& Zhou, S. N. (2002). Endophytic fungi from Musa acuminata leaves and roots in South China. World Journal of Microbiology and Biotechnology, 18, 169-171.

De Bary, A. (1866). Morphologie Physiologie der Pilze. Flechhten und myxomyceten (Vol II). Holmeister's of Physiological Botany, Leipzig.

Domsch, K. H. (2001). Compedium of soil fungi. IHK-VERLAG, Eching.

Ebeltagy, A., Ishioka, K., Sato, T., Suzuki, H., Ye, B., Yamada, T., ... Minamisawa, K. (2011). Endophytic colonization and in plant nitrogen fixation by a Herbaspirillum sp. isolated from wild race species. Applied and Environmental Microbiology, 67, 5285-5292.

FAO (Food and Agriculture organization). (2015). Retrieved June 16, 2018, from http://www.fao.org

Heuer, H., Krsek, M., Baker, P., Smalla, K., \& Wellington, E. M. (1997). Analysis of Actinomicete communities by specific amplification of genes encoding $16 \mathrm{~S}$ gRNA and gel electrophoretic separation in denaturing gradientes. Applied and Environmental Microbiology, 63, 3233-3241.

Karthik, M., Pushpakanth, R., Krishnamoorthy, R., \& Senthikumar, M. (2017). Endophytic bacteria associated with banana cultivars and their inoculation effect on plant growth. The journal of Horticultural Science and Biotechnology, 92, 568-576. https//doi.org/10.1080/1 4620316.2017.1310600

Kavino, M., \& Manoranjithan, S. K. (2018). In vitro bacterization of banana (Musa spp.) with native endophytic and rhizospheric bacterial isolates. Novel ways to combat Fusarium wilt. European Journal of Plant Pathology, 151, 371-387.

Kuklinsky, S. J., Araujo, W. L., Mendes, R., Geraldi, I. O., Pizzirani Kleiner, A. A., \& Azevedo, J. L. (2004). Isolation and characterization of soybean associated bacteria and their potential fror plant growth promotion. Environmental Microbiology, 6, 1244-1251.

Martinez, L., Caballero-Melado, J., Orozco, J., \& Martinez-Romero, E. (2003). Diazotrophyc bacteria associated with banana (Musa spp.). Plant and Soil, 257, 35-47. 
Muthuri, C., Nyambura, N. C., \& Matiru, C. (2012). Isolation and identification of endophytic bacteria of bananas (Musa spp.) in Kenya and their potential as biofertilizers for sustainable banana production. African Journal of Microbiology Research, 6, 6414-6422.

Pereira, J. O., Vieira, M. L. C., \& Azevedo, J. L. (1999). Endophytic fungi from Musa acuminata and their reintroduction into axenic plants. World Journal of Microbiology and Biotechnology, 15(1), 37-40.

Photita, W., Lumyong, S., Lumyong, P., \& Hyde, K. D. (2001). Endophytic fungi of wild banana (Musa acuminata) at Doi Suthep Pul National Park, Thailand. Mycological Research, 105, 1508-1513.

Quecine, M. C., Araujo, W. L., Rossetto, P. B., Ferreira, A., Tsui, S., Lacava, P. T., ... Pizzirani-Kleiner, A. A. (2012). Sugarcane growth promotion by endophytic bacteria. Pantoea agglomerans. Applied Environmental Microbiology, 78, 7511-7518.

Satola, B., Wubbeler, J. H., \& Steinbucher, A. (2013). Metabolic characteristics of the species Variovax parasexus. Applied Microbiology and Biotechnology, 97, 541-560.

Sekhar, A. C., \& Thomas P. (2015). Isolation and identification of shoot-tip associated endophytic bacteria from banana Grand naime and testing for antagonistic activity Oxysporum f. sp, cubense. American Jounal of Plant Sciences, 6, 943-954.

Souza, A., Cruz. J. C., Souza, N. R., Procopio, A. R., \& Silva, G. F. (2014). Endophytic bacteria from banana cultivars and their antifungal activity. Genetics and Molecular Research, 13, 8661-8670. https://doi.org/ $10.4238 / 2014$.October.27.8

Souza, G. L. O. D., Silva, D. F., Nietshe, S., Xavier, A. A., \& Pereira, M. C. T. (2017). Endophytic bacteria used as bioinoculants in micropropagated banana seedlings. Revista Brasileira de Fruticultura, 39. https://doi.org/10.1590/0100-2945201732

Souza, S. A., Xavier, A. A., Costa, M. R., Cardoso, A. M. S., Pereira, M. C. T., \& Nietshe, S. (2013). Endophytic bacterial diversity in banana Prata Anã (Musa spp.)/roots. Genetics and Molecular Biology, 36, 252-264. https://doi.org/10.1590/S1415-47572013000200016

Su, L., Shen, Z., Ruan, Y., Tao, C., Chao, Y., Li, R., \& Shen, Q. (2017). Isolation of antagonistic endophytes from banana roots against Meloidogyne javanica and their effects on soil nematode community. Fontiers of Microbiology, 8, 2070. https://doi.org/10.3389/micb.2017.02070

Thangavelu, R., \& Gopi, M. (2015). Combined application of native Trichoderma isolates possessing multiple functions for the control of Fusarium wilt disease in banana cv. Grand Naine. Biocontrol Science and Technology, 25, 1147-1164. https://doi.org/10.1080/09583157.2015.1036727

Thomas, T., \& Soly, T. A. (2009). Endophytic bacteria associated with growing shoottips of banana (Musa spp.) cv. Grand Naine and the affinity of endophytes to the host. Microbial Ecology, 58, 952.

Ting, A. S. Y., Meon, S., Kadir, J., Radu, S., \& Singh, G. (2008). Endophytic microorganisms as potential growth promoters of banana. Biocontrol, 53, 541-553. https://doi.org/10.1007/s10626-007-9093-1

Welsburg, W. C., Barns, S. M., Dale, A. P., \& Lane, D. J. (1991). 16S ribosomal DNA amplification for phylogenetic study. Journal of Bacteriology, 173, 697-703.

White, T. J., Bruns, T., Lee, S., \& Taylor, J. (1990). Amplification and direct sequencing of fungal ribosomal RNA genes for phylogenetics. In M. Innis, D. Gelland, J. Sansky, \& T. J. White, (Eds.), PCR protocols: A guide to methods and applications (pp. 315-322). San Diego, Academic Press.

Zakaria, L., \& Rahman, N. H. A. (2011). Endophytic Fusarium spp. From wild banana (Musa acuminate) roots. African Journal of Microbiology Research, 5, 3600-3602.

\section{Copyrights}

Copyright for this article is retained by the author (s), with first publication rights granted to the journal.

This is an open-access article distributed under the terms and conditions of the Creative Commons Attribution license (http://creativecommons.org/licenses/by/4.0/). 